\title{
Holothurian sclerites from the Triassic of Jordan and their stratigraphic importance
}

\author{
WALID SADEDDIN \\ Department of Earth and Environmental Sciences, Yarmouk University, Irbid, Jordan.
}

\begin{abstract}
Holothurian sclerites are some of the most stratigraphically important microfossils of the middle Triassic of Jordan. Stratigraphically and palacogeographically important faunas have been obtained by dissolving Triassic carbonate rocks with a dilute acetic acid. The oldest forms, Acanthotheelia jordanica Sadeddin. Priscopedatus quadratus Kozur \& Mostler, and Tetravirga perforata Mostler, occur in the Hisban Formation (Anisian) in the area of the northeast corner of the Dead Sea and Wadi Abu Oneiz. North of this area in Wadi Salit, Ladinian holothurian faunas are especially characterized by the mass occurrence of Schizotheelia jordanica and Schizotheetia multiporata Kozur \& Sadeddin in the lower part of the section (Fassanian) and Theelia rubercula Kristan-Tollmann in the upper part (Longobardian). In spite of some differences, the Jordanian Middle Triassic holothurian faunas are similar to those from the Northern Alps and Germanic Basin. and the Himalayas. As yet, no holothurian sclerites have been recovered from Jordanian Lower or Upper Triassic deposits. J. Micropalaeontol. 15(1): 87-95. April 1996.
\end{abstract}

\section{INTRODUCTION}

Holothurians are a significant group of echinoderms in the modern fauna but have a limited fossil record. They are represented only by sclerites-small calcareous spicules formed in the body wall of the organism. Holothurian sclerites are widespread in micropalaeontological residues but have only been the subject of limited study, e.g. Frizzell \& Exline $(1955 a, b)$, Gilliland (1993).

Holothurian sclerites from Jordan were unknown until Kozur \& Sadeddin (1990) described the first holothurian sclerites from Middle Jurassic carbonate rocks. Later, Sadeddin (1991) described the new holothurian species Acanthotheelia jordanica from early Middle Triassic rocks of the Pelsonian (middle Anisian). Sadeddin \& Kozur (1992) discussed the geographic distribution of Theelia tubercula Kristan-Tollmann and its Triassic distribution. Kozur \& Sadeddin (1992) described the new family Schizotheelidae and two new species; Schizotheelia jordanica and $S$. multiporaia and the new genus Schizoacanthotheelia from the Fassanian (early Ladinian). Further investigations by dissolving Triassic carbonate rocks from different localities using dilute acetic acid solutions indicate that Triassic sediments in Jordan frequently contain holothurian sclerites (see Fig. 2). Upper Cretaceous carbonate rocks (Cenomanian-Turonian) have also been found to be rich in holothurian sclerites (Sadeddin, in preparation).

In this paper, Triassic rock sequences from various localities in which holothurian sclerites occur are briefly discussed; holothurian sclerites are described from strata of the Anisian (Hisban Formation) and Ladinian. To date, no holothurian sclerites have been obtained from the lower Triassic (Skythian) of Jordan. Holothurian sclerites from the late Triassic (Camian) outcrops have not yet been documented (although the lower part of the rock sequences at Wadi Huni could be placed into Cordevolian (lower Carnian).
All studied specimens are deposited in the Department of Earth and Environmental Sciences, Yarmouk University, Irbid, Jordan.

\section{HOLOTHURIAN-BEARING SAMPLES - LITHOLOGY AND PALAEONTOLOGY}

Northeast corner of the Dead Sea (Area 1 of Fig. 1)

Samples S1, 7b, 8b, TJ1, TJ6, TJ7, TJ17 and TJ19 were taken from the Hisban Formation (Hisban Limestone Member) and the Salit Formation from Wadi Hisban and south of Jalda (Fig. 1a).

The Hisban Limestone Member consists of massive thick grey limestone beds in the base ( $\mathrm{S} 1$ ), followed by wavy bedded grey limestone 'Wellenkalk' (7b), fossiliferous marly, grey to yellowish limestone (8b) with frequent bivalves (Placunopsis sp.), brachiopods (Coenothyris vulgaris, Aulacothyris cf. A. agnusta) and cephalopods (Beneckeia spp., Germanonautilus bidorsatus) and thin layers of yellowish (subordinate reddish) marl.

Sample S1 which was taken from the lower part of the Hisban Limestone Member (massive limestone) at Wadi Siyala contains the holothurian sclerites: Theelia patinaformis Mostler, Calclamna germanica Frizzell and Exline, Calclamna trettoensis Mostler, Theelia zapfei Kozur \& Mostler.

Sample 76 from the grey wavy limestone beds (in Wadi Hisban) contains a rich assemblage of holothurian sclerites comprising mostly the genus Calclamna: Calclamna sp., $C$. nuda Mostler, $C$. trettoensis Mostler and few Theelia (Theelia cf. muelleri Kozer \& Mostler).

Sample $8 \mathrm{~b}$ was taken from the fossiliferous marly limestone $10 \mathrm{~m}$ above sample $7 \mathrm{~b}$. It contained a rich sclerite fauna dominated by species of Theelia such as Theelia germanica Kozur, Theelia planorbicula Mostler, Theelia sp., Achistrum monochordata Hodson et al., Calcancora sp. 


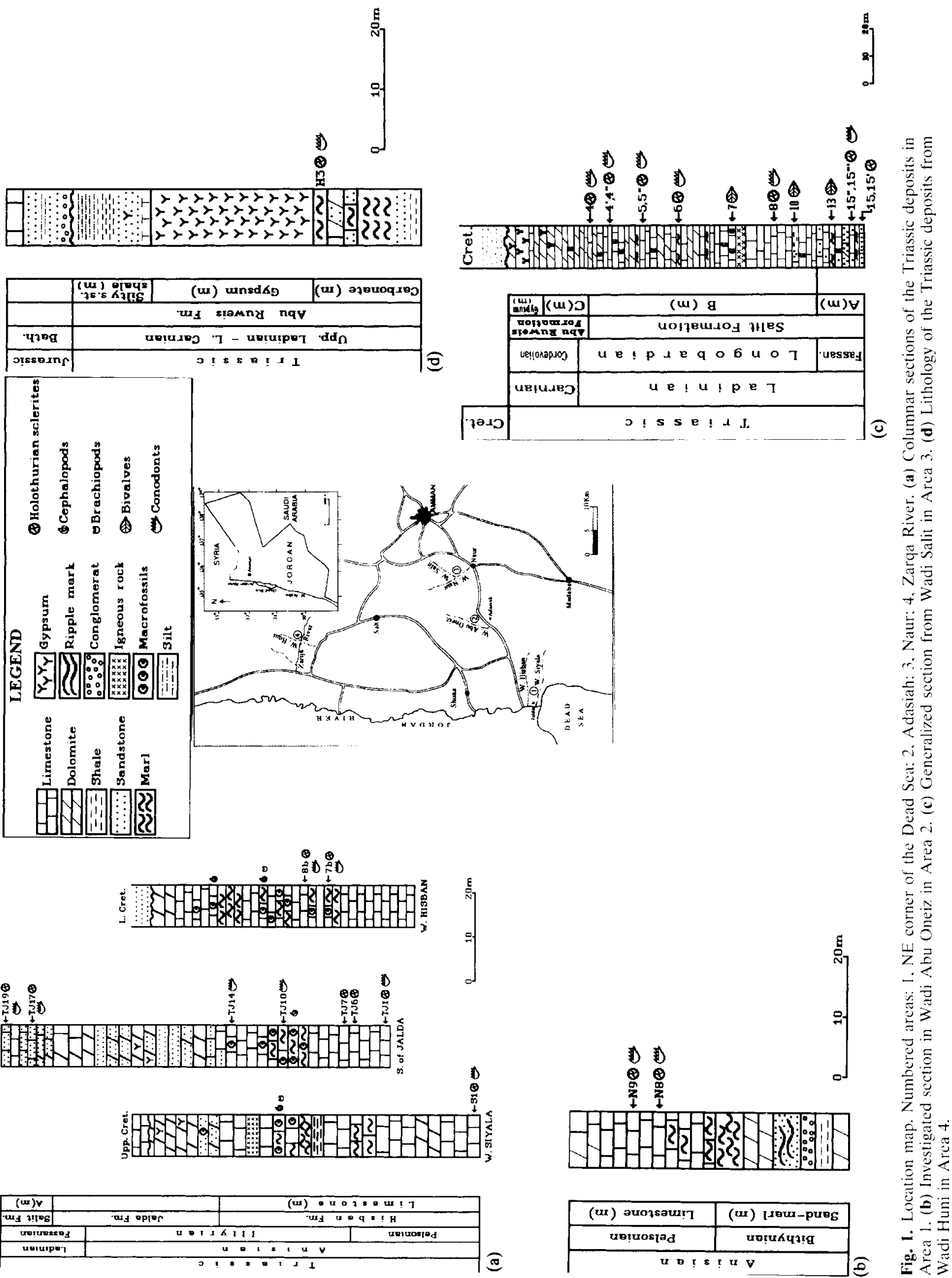




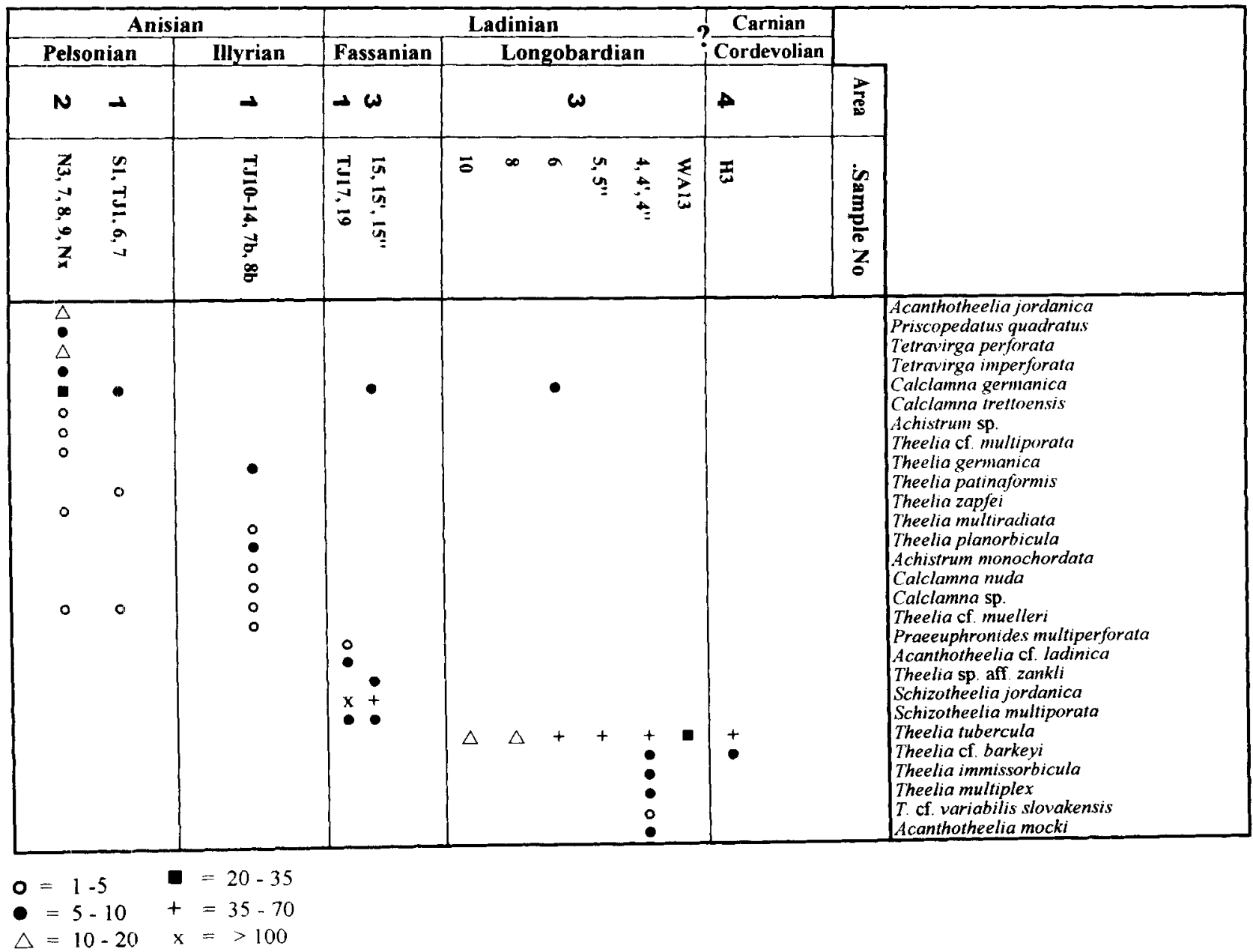

Fig. 2. Stratigraphic distribution of the holothurian sclerites found in the present study.

Samples TJ17 and TJ19 were collected from the upper portion of the Jalda section which belongs to the lower part of Salit Formation (lower part of member A) which consists of sandy limestone beds with Trigonodus, dolomitic limestone and sandy dolomitic limestone. These samples yield the following holothurian sclerites: Schizotheelia jorlanica Kozur \& Sadeddin, Schizotheelia multiporata Kozur \& Sadeddin (dominant), Priscopedatus sp. (few), Theelia sp. (solitary).

\section{Adasiah (Area 2 of Fig. 1)}

Samples N8 (NT5) and N9 were collected from the Hisban Formation (lower part of the Hisban Limestone Member) at Wadi Abu Oneiz $2.5 \mathrm{~km}$ SW of Adasiah (Fig. 1b). Both samples were taken from the massive, thick bedded grey limestone ( $\mathrm{N} 9$ is $5 \mathrm{~m}$ above $\mathrm{N} 8$ ). They yielded rich holothurian sclerite faunas containing Tetravirga perforata Mostler, Calclamna germanica Frizzell \& Exline, Calclamna sp., Achistrum sp., Priscopedatus quadratus Kozur \& Mostler, Acanthotheelia jordanica Sadeddin, Theelia sp., Theelia zapfei. Kozur \& Mostler.
Naur (Area 3 of Fig. 1)

Samples 15, 15", 8, 4" and 4, were collected from the Salit Formation at Wadi Salit west of Naur (Fig. 1c). Samples 15 and $15^{\prime \prime}$ were taken from the sandy limestones (lower part of member A). In these samples abundant holothurian sclerite faunas have been found that are dominated by the genus Schizotheelia, and include Schizotheelia jordanica Kozur \& Sadeddin, Schizotheelia multiporata Kozur \& Sadeddin. Also present are Acanthotheelia cf. A. ladinica Kozur \& Mostler, Theelia sp. aff. T. zankli Kozur \& Simon, a few unidentified sclerites (poorly preserved Priscopedatus) and a rich conodont assemblage containing among other forms frequent Pseudofurnishius priscus Sadeddin.

The holothurian-bearing samples $8,4^{\prime \prime}$, and 4 were taken from member $B$ of the Salit Formation which consists of limestones, dolomites, dolomitic limestone, marls and shales in the form of streaks and lenticular deposits. Sample 8, collected from limestone beds with Trigonodus and Posidonia that are overlain by a $4 \mathrm{~m}$ volcanic intrusion (tracyandesite sill), contains the holothurian sclerite Theelia ubercula Kristan-Tollmann and also yields frequent conodonts (Pseudofurnishius sosioensis Gullo \& Kozur). 
Samples 4" and 4 were collected from the upper portion of the Salit Formation (upper part of member B) which consists of $30 \mathrm{~m}$ limestonc with nodular, fossiliferous layers and dolomites containing some banded, platy fossiliferous layers. Sample $4^{\prime \prime}$ contains a rich assemblage of holothurians belonging to Theelia cf. T. barkeyi Kozur \& Simon, $T$. immissorbicula Mostler, T. multiplex Speckmann, Theelia cf. T.multiplex Speckmann, Theelia cf. T.variabilis slovakensis Kozur and Mock, and Theelia sp. Sample 4, collected from the same beds ( $10 \mathrm{~m}$ above $\left.4^{\prime \prime}\right)$, contains exclusively Theelia ubercula Kristan-Tollmann. Sample $4^{\prime \prime}$ also contained frequent conodonts including Pseudofurnishius murcianus Van Den Boogaard (exclusively monoplatform type) and Budurovignathus mungoensis (Dicbel).

\section{Zarqa River (Area 4 of Fig. 1)}

Sample $\mathrm{H} 3$ belongs to the Abu Ruweis Formation (Fig.1d) from Wadi Huni (basal part, carbonate member) which comprises dolomites, dolomitic limestone, marly limestone, marl, sandy marl and cellular dolomite. This sample, which was collected from the marly limestone contains holothurian sclerites belonging to Theelia tubercula Kristan-Tollmann, Theelia cf. T. barkeyi Kozur \& Simon and frequent conodonts comprising exclusively Burdurovignathus mungoensis (Diebel) and B. mostleri Kozur. The lower part of this sequence (sandy marl) contains ostracods: Lutkevichinella egeleri Kozur.

\section{AGE OF THE ROCK SEQUENCES WHERE HOLOTHURIAN SCLERITES HAVE BEEN FOUND}

The age of the Triassic rock sequences in Jordan were determined primarily by the use of conodonts (e.g. Kozur, 1968, 1974, 1980, 1989; Gullo \& Kozur, 1989; Sadeddin, 1990; Sadeddin \& Kozur, 1992), partly by cephalopods, brachiopods and pelecypods (e.g. Cox, 1924: Wagner, 1934; Parnes, 1975). Conodonts from the study area have been investigated in detail and documented by Sadeddin (in press, Paläontographica abt. A)

\section{Wadi Hishan section (Fig. 1a)}

Based on conodonts (belonging to Neogondolella bulgarica), a middle Anisian (Pelsonian) age is warranted for the lower part of this section. The presence of Paragondolella hanbulogi in sample 7b, Gondolella constricta in sample 8b, and accompanying macrofossils such as ammonites (Beneckeia levantina) and brachiopods (Coenothyris vulgaris) indicate an upper Anisian (Illyrian) age for the middle and upper part of this succession.

\section{Jalda section (Fig. 1a)}

The holothurian-bearing samples TJ1, TJ6 and TJ7 from the basal part of Jalda section yielded conodonts referred to Neogondolella bulgarica indicating a middle Anisian age (Kozur, 1989). Samples TJ10-TJ14 from the middle part of the Jalda section contain poorly preserved holothurian scierites (Theelia spp.). The accompanying conodonts belonging to Paragondolella hanbulogi, Gondolella bifurcata, Gondolella constricta and macrofossils comprising ammonites (Benekeia sp.), brachiopods (Coenothyris vulgaris) and bivalves (Placunopsis sp.) indicate an upper
Anisian age. The basal portion of the upper part of the Jalda section consists of fossil-free, brownish weathered, hypersaline dolomites, cellular dolomites, sandstones and dolomitic sandstones. These sediments correspond in facies to the higher upper part of the hypersaline Germanic middle Muschelkalk (Kozur, 1974). They are also overlain by the basal beds of the upper Muschelkalk, which consist of sandy limestones, dolomites, dolomitic limestones, often with mass occurrences of Trigonodus (samples TJ17-TJ19) and containing conodonts (Pseudofurnishius priscus, $P$. siyalaensis) of Fassanian (early Ladinian) age (Sadeddin, 1990: Sadeddin \& Kozur, 1992). These fossil-free sediments could be placed into the Illyrian (uppermost Anisian).

The lower and middle part of the Jalda section can be correlated with the section of Wadi Hisban, whereas strata referred to the upper part of the Jalda section are not exposed in Wadi Hisban.

\section{Abu Oneiz section (Fig. 1b)}

No age diagnostic microfossils have been found in the basal part of this section. Based on lithostratigraphic correlation with analogous sequences in area 1, a lower Anisian age is justificd for this part. In the middle and upper part of this section which represents the Hisban Limestone Member, holothurian faunas have been found (samples N3, N7, N8, $\mathrm{N} 9$, and $\mathrm{Nx}$ ) that are especially characterized by the oldest Acanthotheelia (Acanthotheelia jordanica Sadeddin, 1991). A Pelsonian (middle Anisian) age (well dated by a conodont fauna collected by the author with Nicoraella germanica, Nicoraella kockeli and Neogondolella bulgarica) is warranted for the middle and upper part of Abu Oneiz sequence.

\section{Wadi Salit section (Fig. 1c)}

The basal portion of this and the uppermost portion of the Jalda section are very similar. Samples $15,15^{\prime}, 15^{\prime \prime}$ and $15^{\prime \prime \prime}$ contain abundant holothurians that are also especially characterized by Schizotheelia jordanica and Schizotheelia multiporata. The accompanying conodonts collected by the author (Pseudofurnishius priscus) are analogous to those of the upper portion of Jalda section, indicating a Fassanian (early Ladinian) age. No holothurian sclerites have been found in the samples directly above samples $14,13,12,11$, from the lower part of this section. The presence of Budurovignathus truempyi Hirsch in sample 12 indicates an uppermost Fassanian (Fassanian/ Longbardian) age for this part of the section. In samples $10,8,7,7^{\prime \prime}, 6,6^{\prime \prime}, 5,5^{\prime \prime}, 4,4^{\prime}$ and 4 " holothurian sclerites have been recorded that are characterized by the frequent occurrence of Theelia tubercula which appears in all samples except sample 7 and $7^{\prime \prime}$. Samples 10 and 8 contain conodonts belonging to Pseudofurnishius sosioensis which Gullo \& Kozur (1989) placed in the lower Longobardian; macrofossils have also been reported comprising Trigonodus sp. (sample 10), and Posidonia wengensis (sample 8). Placunopsis flabellum has been found in the horizon from which samples 7 and $7 "$ were collected. These samples and samples $6,6^{\prime}, 6^{\prime \prime}, 5$ and $5^{\prime \prime}$ have yielded highly evolved representatives of Pseudofurnishius murcianus (biplatform type) and a middle Longobardian 
age is indicated for this part of the succession. In samples 4 , $4^{\prime}$ and $4^{\prime \prime}$ which contain frequent Theelia tubercula, conodonts comprising Pseudofurnishius murcianus (exclusively monoplatform type) and Budurovignathus mungoensis, partly transitional to Budurovignathus diebeli, have been found. This level $\left(4,4^{\prime}, 4^{\prime \prime}\right)$ belongs to the higher Longobardian-Ladinian/Carnian boundary. The next higher beds which consist of dolomite, gypsum, cellular dolomite are analogous to the germanic lower 'Gipskeuper' and the adjacent areas. Based on lithostratigraphic correlation with these sequences, an early Carnian age is indicated for these beds.

\section{Wadi Huni section (Fig. 1d)}

Based on the conodonts Budurovignathus mungoensis and B. mostleri an uppermost Longobardian-lowest Cordevolian age (Landinian/Carnian boundary) is indicated for the holothurian-bearing lower part of this section.

The middle and upper part of this section (gypsum and shale members of Abu Ruwais Formation) overlaying the carbonate member, is correlatable with the top part of the Salit section (shale member is missing) and analogous to the lower 'Gipskeuper' of the Germanic Basin and the adjacent areas (lower member of Mohilla Formation, Israel). On the basis of the lithostratigraphic correlation with the aforementioned sequences, an early Carnian age is warranted for the middle and upper part of Wadi Huni section.

\section{DISCUSSION}

The Triassic of Jordan belonged to a marginal sea south of the southern Tethys. In Skythian sediments which are exposed at the eastern rim of the Dead Sea (twenty samples have been studied), no holothurian sclerites have been found as yet. The first association appears in Anisian carbonate rocks from Wadi Siyala (area 1, Fig. 1, NE corner of the Dead Sea) and Wadi Abu Oneiz (area 2, Fig. 1, Adasiah) consisting of Calclamna germanica Frizzell and Exline, Calclamna trettoensis Mostler, Calclamna sp., Priscopedatus quadratus Kozur \& Mostler, Theelia cf. $T$. multiporata Kozur, Theelia zapfei Kozur \& Mostler, Tetravirga imperforata Frizzell and Exline and Tetravirga perforata Mostler.

These associations are characterized by the frequent occurrence of Acanthotheelta jordanica Sadeddin which appears in the Pelsonian of Jordan. According to Mostler (1970, 1973) Acanthotheelia Frizzell \& Exline appears in the Illyrian (Upper Anisian) of the northern calcareous Alps, Hungary and western Carpathians. Kozur (1969) and Kozur \& Mostler (1970) did not report Acanthotheelia in the holothurian sclerite associations from the Pelsonian (Middle Anisian) of the Germanic Basin.

The early Middle Triassic (Anisian) holothurians from Jordan are, with some differences, similar to those of North Tethyan faunas known from the northern Alps, western Carpathians and the Germanic Basin (Sadeddin, 1991)

In the Illyrian (Upper Anisian) from Wadi Hisban and Wadi Siyala (Fig.1a) Calclamna sp., Calclamna nuda
Mostler, Calclamna trettoensis Mostler, Theelia germanica Kozur, Theelia cf. T. muelleri Kozur \& Mostler, Theelia planorbicula Mostler, Theelia multiradiata Kozur, Theelia sp., Achistrum monochordata Hodson, Harris and Lawson are present.

The Fassanian (early Ladinian) holothurian sclerite associations from Wadi Siyala (top of Jalda section, Fig.1a) and from Wadi Salit section (Fig.1c) are characterized by the mass occurrence of Schizotheelia jordanica Kozur \& Sadeddin and Schizotheelia multiporata Kozur \& Sadeddin. In addition to Schizotheelia, Acanthotheelia cf. A. ladinica Kozur \& Mostler are also present. Forms without stratigraphic value such as Calclamna germanica Frizzell \& Exline, Praeeuphronides multiperforata Mostler and poorly preserved Priscopedatus occur (see Kozur \& Sadeddin, 1992).

The Longobardian (Upper Ladinian)-Lower Cordevolian (Lower Carnian) holothurian associations from Jordan which consist of: Achistrum sp., Calclamna germanica Frizzell \& Exline, Theelia cf. T.barkeyi Kozur \& Simon, Theelia sp., Theelia cf. T. variabilis slovakensis Kozur \& Mock, Theelia immissorbicula Mostler and Theelia multiplex Speckmann are characterized by the frequent occurrence of Theelia ubercula Kristan-Tollmann. In Jordan, which belongs to the West Mediterranean-Arabian faunal province of the southern Tethys (sensu Kozur \& Mostler, 1971) late Middle Triassic (Ladinian) rocks yield the same holothurian species that occur in other regions of this province (Kozur \& Sadeddin, 1992).

Theelia tubercula which has been regarded so far as an index species for the Cordevolian (carly Carnian) was found in the early Longbardian (early late Ladinian) of Jordan together with the conodont species Pseudofurnishius sosionsis Gullo \& Kozur. It occurs in shallow-water sediments as well as in pelagic sediments, is regarded as a palaeogeographic indicator for the southern Tethys and its marginal seas, and has the same distribution as the conodont genus Pseudofurnishius Sadeddin \& Kozur (1992), see also Kozur \& Simon (1972), Kozur et al. (1974), Kozur et al. (1985). In the higher sediments (Wadi Salit and Wadi Huni, Fig.1c, d) which belong most probably to the early Carnian, no holothurian sclerites have been found.

In addition to holothurian sclerites crinoid debris, echinoids, conodonts, ostracods, foraminiferans, microbivalves, microgastropods and fish remains are present in most studied samples. No relationship could be discerned between the presence or abundance of holothurians with any of these fossil groups.

\section{SYSTEMATIC PALAEONTOLOGY}

The classification followed is that of Frizzell \& Exline (1955b), which is based on the morphology of the sclerites. and has an artificial character.

Family Stichopitidae Frizzell \& Exlinc, $1955 b$ Genus Tetravirga Frizzell \& Exline, 1955b Tetravirga perforata Mostler, 1968 (Pl. 1, fig. 1) 

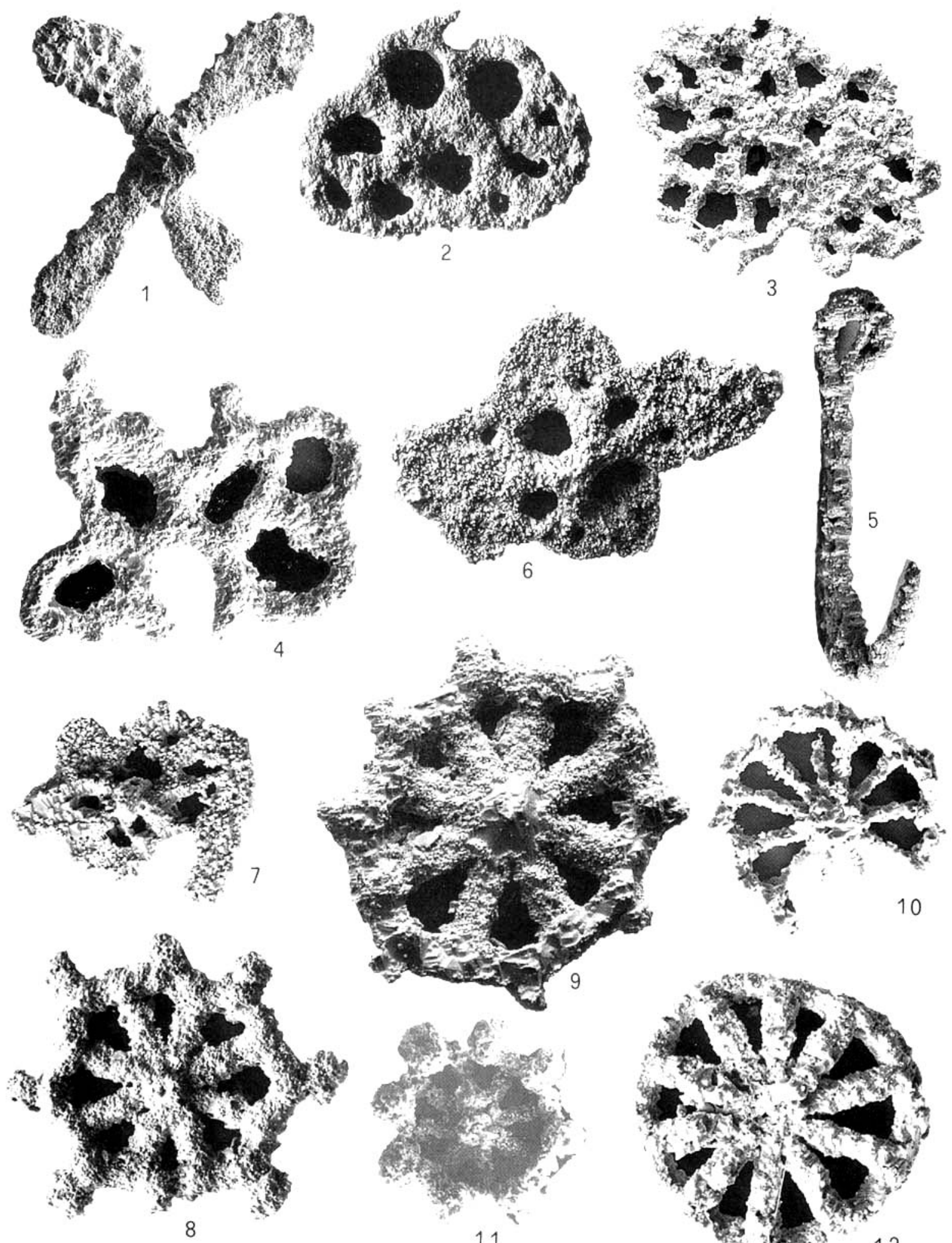

11

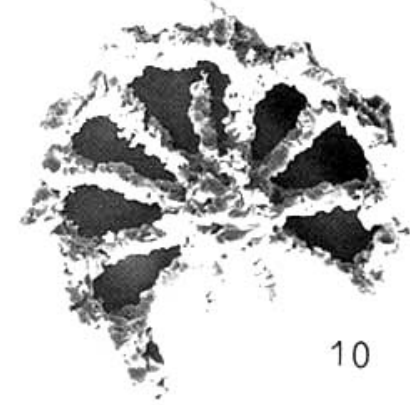

Plate 1 
1968c Tetravirga perforata n. sp. Mostler: 10, pl. 1, figs 6-7. Material. 15 specimens.

Occurrence. Pelsonian of Jordan. Anisian; Germanic and Alpine Triassic (Pelsonian-Illyrian).

Family Calclamnidae Frizzell \& Exline, 1955b

Genus Calclamna Frizzell \& Exline, $1955 b$

Calclamna germanica Frizzell \& Exline, 1955b

(Pl. 1, figs 2, 4)

1955h Calclamna germanica n. sp. Frizzell \& Exline: 76-77, pl. 2, figs $1-5$.

Material. 28 specimens.

Occurrence. Pelsonian, Illyrian of Jordan (Hisban Limestone): Anisian-Liassic.

Remarks. $C$. germanica is very much like $C$. norica Kozur \& Mock. 1972 from lower Norian of Slovakia, differing in the smaller size, fewer perforations (15-38 in C. norica). The central holes of $C$. germanica are essentially larger than the surrounding holes, while those of $C$. norica are of same size or slightly larger.

Calclamna trettoensis Mostler, 1979

(Pl. 1, fig. 3)

1979 Calclamna trettoensis n. sp. Mostler: 337-338, pl. 3, figs. 1-11, 13.

Material. 3 specimens.

Occurrence. Pelsonian of Jordan; Pelsonian of Tretto (Vicentin, Italy).

Remarks. Calclamna trettoensis shows some similarities to C. germanica Frizzell \& Exline, 1955, differing in having many more holes, irregular outline and smaller central holes. C.norica Kozur \& Mock, 1972 is larger and has rounded to oval, larger holes (especially the central holes).

Family Achistridae Frizzell \& Exline, 1955

Genus Achistrum Etheridge, 1881 emend Frizzel \& Exline, 1955

Achistrum monochordata Hodson, Harris \& Lawson, 1956 (PI. 1, fig. 5)

1955 Calcligula hucki n. sp. Frizzell \& Exline: 70-71, pl. 1, fig. 28.

1956 Achistrum monochordata n. sp. Hodson, Harris \& Lawson: 340-341. text-figs 10-11.

1978 Achistrum triassicum Gadzicki, Kozur, Mock \& Trammer: 360 , pl. 49, figs 4-6.
1987 Achistrum bichordata Soodan \& Whatley: 186, pl. 1, fig. F.

1992 Achistrum monochordata Gilliland: 194-196, pl. 4, figs 1-8 (with synonyms).

Occurrence. Illyrian (middle Triassic) of Jordan; early Carboniferous to early Cretaceous worldwide.

Remarks. The single specimen present, recorded from the Middle Triassic (fossiliferous marly limestone) differs from all other forms of the genus by commonly having a single bar across the eye. The reporting of this species from carly Carboniferous to early Cretaceous by many authors, contradicts the statement of Frizzell \& E: ine (1966) that the eye of Achistrum is simple in earlier forms, but becomes cross-barred in later forms.

Family Priscopedatidae Frizzell \& Exline, 1955

Genus Priscopedatus Schlumberger, 1890, emend. Frizzell \& Exline

Priscopedatus quadratus Kozur \& Mostler, 1970

(Pl. 1, fig. $6-7$ )

1970 Priscopedatus quadratus n. sp. Kozur \& Mostler: 371-372, pl. 3, figs 2-3.

Material. 4 specimens.

Occurrence. Pelsonian of Jordan: Pelsonian of germanic basin; Pelsonian of Tethyan Triassic.

Family Theeliidae Frizzel \& Exline, $1955 b$

Genus Acanthotheelia Frizzel \& Exline, $1955 b$

Acanthotheelia jordanica Sadeddin, 1991

(Pl. 1, fig. 1-3)

1991 Acanthotheelia jordanica n. sp. Sadeddin: 234-235; pl. 1, figs. $1-5$.

Material. 14 specimens.

Occurrence. Pelsonian of Jordan (in the lower part of Hisban Limestone) $25 \mathrm{~m}$ below the 'Terebratel beds' with Beneckeia spp.

Description. Wheel-like large sclerite with 7-9 spokes and subcircular to polygonal outline. Periphery always with one large spine opposite to every interspoke space. Distal ends of spines often expanded knob-like. Rim moderately broad, its inner margin not or only slightly bent inward. Spokes moderately long, straight, mostly broad but some times narrow, of equal width throughout. Hub small to medium-sized. Upper surface of hub convex and sometimes higher than upper margin of rim. Lower surface slightly convex to plane.

\section{Explanation of Plate 1}

Fig. 1. Tetravirga perforata Mostler, sample N8, Pelsonian. Repository number \$1/8/71/88, Wadi Abu Oneiz, $\times 155$. Fig. 2. Calclamna germanica Frizacll \& Exline, sample N8. Pelsonian, Rep. no. S1/8/66/88, Wadi Abu Oneiz, ×225. Fig. 3. Calclamna trettoensis Mostler, sample 7b. Illyrian. Rep. no. S1/14/168/88. Wadi Hisban, $\times 165$. Fig. 4. Calclamma germanica Frizzell \& Exline, sample 7b, Illyrian, Rep. no. S1/14/183/88. Wadi Hisban, $\times 165$. Fig. 5. Achistrum monochordata Hodson, Harris \& Lawson, sample 8b, 1llyrian, Rep. no. S1/11/129/88, Wadi Hisban, $\times 155$. Figs 6-7. Priscopedatus quadratus Kozur \& Mostler. Fig. 6: sample N9, Pelsonian, Rep. no. SI/8/64/88, Wadi Abu Oneiz, $\times 220$ : Fig. 7: sample N9. Pelsonian, Rep. no. S1/18/293/88, Wadi Abu Oneiz, $\times 230$. Figs 8-9. Acanthotheelia jordanica Sadeddin, sample N8, Pelsonian, Rep. no. S1/9/77,82/88. Wadi Abu Oneiz, × 135. Fig. 10. Acanthotheelia cf. A. ladinica Kozur \& Mostler, sample 15, Fassanian (early Ladinian), Rep. no. S1/1/17/88, upper view Wadi Salit, $\times 280$. Fig. 11. Acanthotheelia mocki Kozur, sample WA 13, Longobardian (late Ladininan), Rep. no. 42/93, Naur area, $\times 150$. Fig. 12. Theelia zapfei Kozur \& Mostler, sample TJ6, Pelsonian. Rep.no. S1/10/113/88, lower view. $2 \mathrm{~km}$ south of Jalda, $\times 200$. 

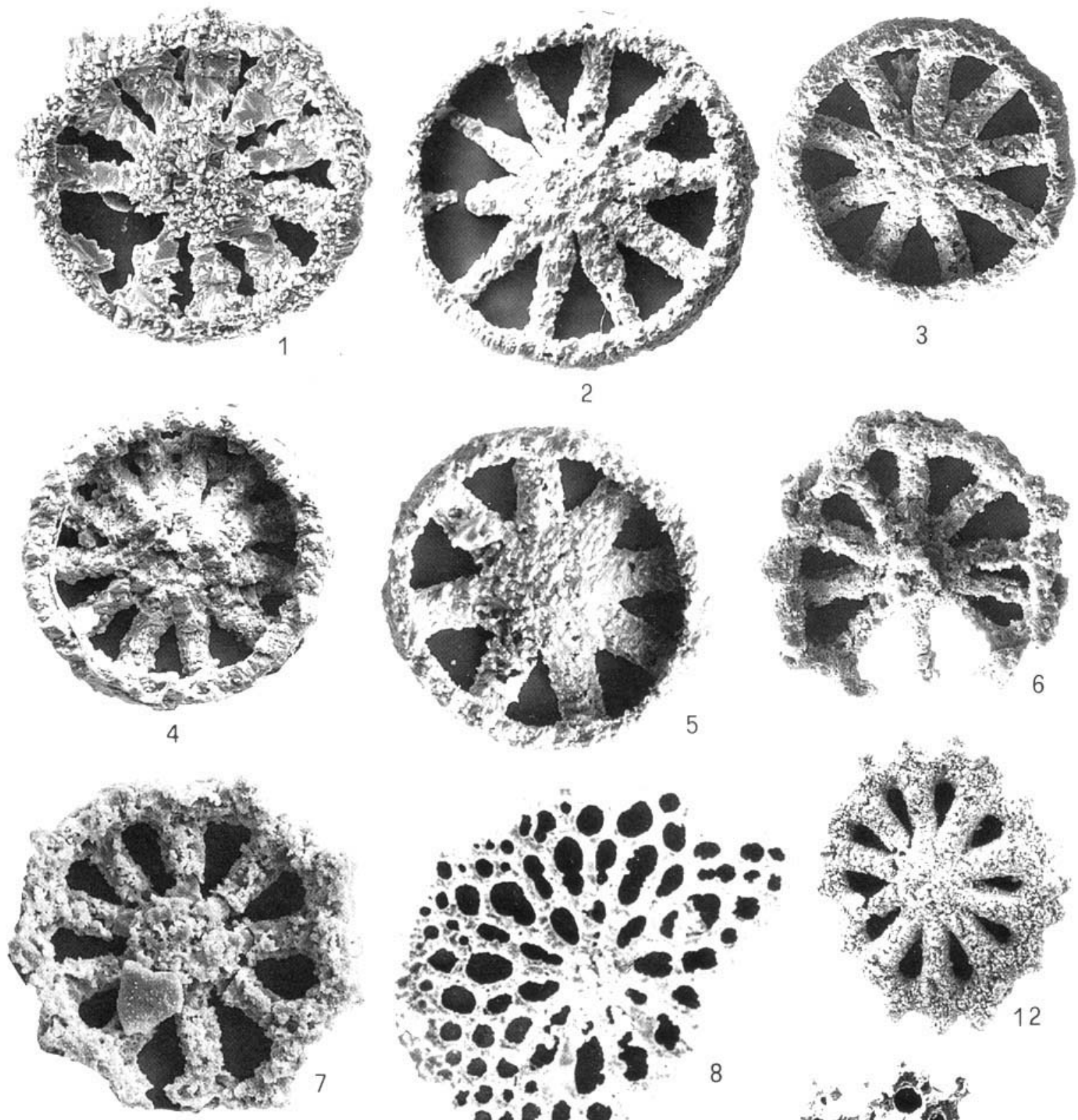

क जी है
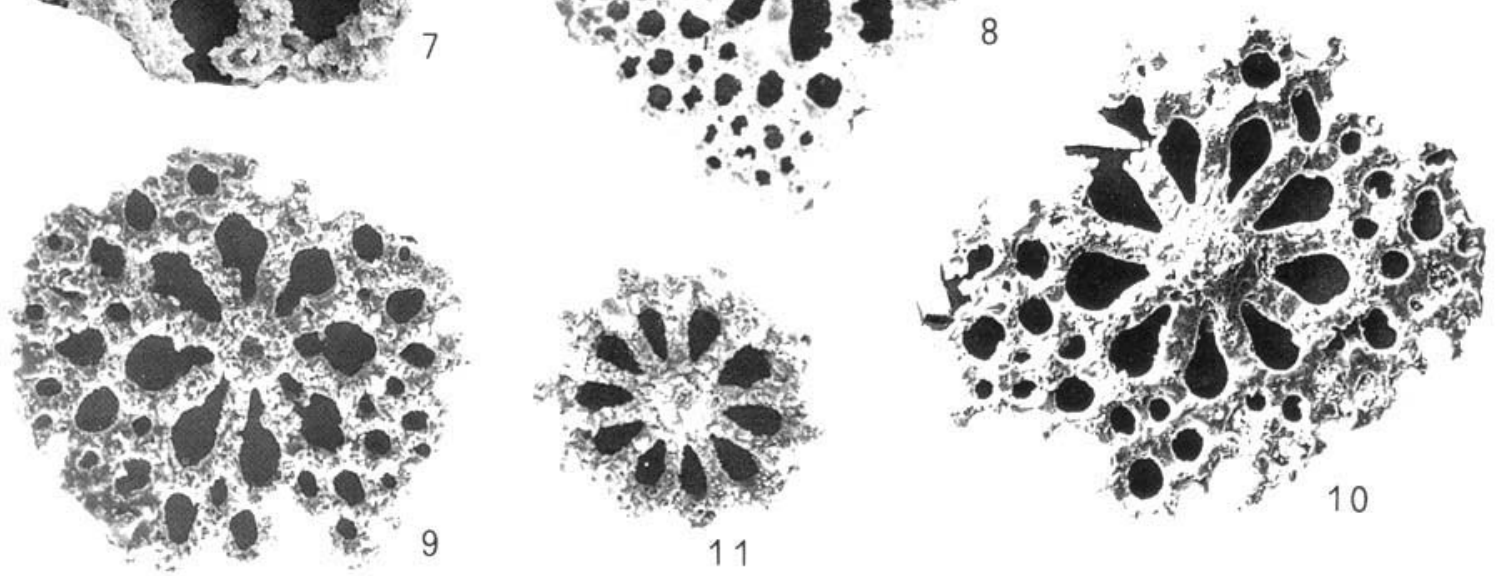

Plate 2 
Remarks. Acanthotheelia jordanica is very similar to Acanthotheetia mocki Kozur, 1985 and A. virgiliae Kozur, 1985 (from the Cordevolian of Spain), but both are smaller (for measurements, see Sadeddin, 1991) than $A$. jordanica. The rim of $A$. mocki is broader than the rim of $A$. jordanica and the rim of $A$. jordanica is broader than the rim of $A$. virgiliae.

Acanthotheelia cf. A. ladinica Kozur \& Mostler, 1971

(Pl. 1, fig. 10)

Occurrence. Fassanian (Lower Ladinian) of Jordan, together with Pseudofurnishius priscus, $P$. siyalaensis (Conodonta) and Schizotheelia multiporata, Schizotheelia jordanica (Holothuroidea).

Remarks. This form (only one specimen is present) differs from A. ladinica Kozur \& Mostler by its smaller size, shorter spokes. Both the lower and upper surface of the hub in A. ladinica Kozur \& Mostler are flat.

Acanthotheelia mocki Kozur, 1985

(Pl. 1, fig. 11)

1985 Acanthotheelia mocki Kozur Kozur et al.: 106, pl. 1, figs $1-4$.

Material. 9 specimens.

Occurrence. Cordevolian (early Carnian) of Spain; Longobardian (late Ladinian) of Jordan.

Remarks. See $A$. jordanica.

Theelia cf. T. barkeyi Kozur \& Simon, 1972

(Pl. 3, figs 3-4)

Occurrence. Uppermost Longobardian (late Ladinian) of Jordan.

Remarks. This form differs from $T$. barkeyi Kozur \& Simon by its shorter, wider spokes.

Theelia germanica Kozur, 1969

(Pl. 2, fig. 4)

1969 Theelia germanica n. sp. Kozur: 148-152, pl. 1, figs 1 3, 6: pl. 2, figs $1-2,5-8$.

1970 Theelia germanica Kozur \& Mostler: 377-378, pl. 2, figs $1-8$.

Material. 7 specimens.

Occurrence. Illyrian of Jordan (middle Triassic) from the fossiliferous marly limestone beds 'Terebratel beds' with Beneckei levantina (Hisban Formation); Lower AnisianPelsonian (middle Anisian) of germanic basin; from the Triassic of Spiti (Himalaya, India).
Remarks. Theelia immissorbicula Mostler, $1968 b$ which is known from late Anisian-late Norian, a probable synonym of $T$. germanica. However, $T$. immissorbicula has a very high hub (considerably higher than the plane of the rim). T. subcirculata Mostler, $1968 \mathrm{~b}$ is also similar to $T$. germanica but it differs in having predominantly subcircular, undulating outline and a smaller hub. $T$. synapta Gilliland, 1992, shows some similarity, but it is distinguished by the number of spokes (7-15, predominantly $10-13)$, the teethed inner margin of the rim and the median ridge on the spokes. The illustrated specimen on plate, 3, fig. 9, may be a synonym of $T$. germanica. $T$. zapfei Kozur \& Mostler, 1970 is very much like $T$. germanica and may by identical to it. However, it has fewer spokes and a less inwardly bent margin.

Theelia immissorbicula Mostler, $1968 \mathrm{~b}$ emend. Kozur \& Mock, 1972

(Pl. 3, figs. 6, 8)

1968b Theelia immissorbicula n. sp. Mostler: 26-27, pl. 5, fig. 1.

Occurrence. Uppermost Longobardian (late Ladinian) of Jordan, Pelsonian, early Norian of Alps ; late Anisian and Carnian of Bulgaria.

Theelia cf. $\boldsymbol{T}$. muelleri Kozur \& Mostler, 1970

(Pl. 2, fig. 1)

Occurrence. Illyrian of Jordan.

Remarks. This form (only one specimen is present) differs from $T$. muelleri Kozur \& Mostler: the hub of $T$. muelleri is smaller and lies obviously below the upper plane of the rim and the lower surface of the hub is plane to slightly concave.

Theelia multiplex Speckmann, 1968

(Pl. 3, figs 9-10)

1968 Theelia multiplex n. sp. Speckmann: 4, figs 1-3.

Occurrence. Uppermost Longobardian (late Ladinian) of Jordan, together with Pseudofurnishius murcianus, Wadi Salit section: it is also reported from Cassian beds of eastern Alps (late Ladinian).

Theelia cf. T. multiplex Speckmann, 1968 (Pl. 3, figs 11-14)

Occurrence. Uppermost Longobardian (late Ladinian) of Jordan.

Remarks. This form differs from $T$. multiplex by having wider spokes with the same width throughout.

Theelia planorbicula Mostler, 1968

(Pl. 2, figs 2-3)

\section{Explanation of Plate 2}

Fig. 1. Theelia cf. T. muelleri Kozur \& Mostler, sample 7b, Illyrian, Rep. no. S1/14/167/88, Wadi Hisban, $\times 165$. Figs 2-3. Theelia planorbicula Mostler, Fig. 2: sample 8b, Illyrian, Rep.no. S1/10/112/88, ×200: Fig. 3: Sample 8b, Illyrian. Rep. no. S1/11/118/88, ×165, Wadi Hisban. Fig. 4. Theelia germanica Kozur, sample 8b, Illyrian. Rep. no. S1/11/116/88. Wadi Hisban, $\times 165$. Fig. 5. Theelia cf. T. zawidzkae Kozur \& Mock. sample 8b, Hllyrian. Rep.no. S1/10/98/88, Wadi Hisban, $\times 220$. Figs 6-7. Theelia n. sp.aff. zankli Kozur \& Simon, sample 15, Fassanian, Rep. no. S1/1/4,1/88, Fig. 6: $\times 220$; Fig.7: $\times 380$, Wadi Salit. Fig. 8. Schizotheelia multiporata Kozur \& Sadeddin, sample TJ17, Fassanian. Rep. no. S3/26/5/88, $2 \mathrm{~km}$ south of Jalda, $\times 200$. Figs 9-10. Schizotheelia jordanica Kozur \& Sadeddin, sample 15" Fassanian. Rep. no. W2/5/24.13/89; Fig. 9: $\times 130$; Fig. 10: $\times 200$, Wadi Salit. Figs 11-12. Theelia tubercula Kristan-Tollmann, sample 8 , lower Longobardian (early middle Ladinian). Rep. no. W2/7/16,19/90, upper view, $\times 180$, Wadi Salit. 


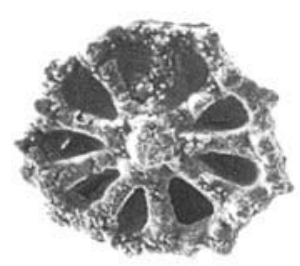

1

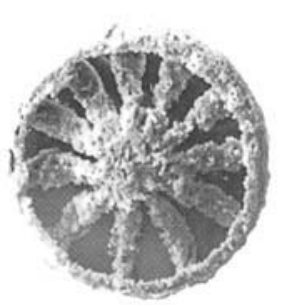

5

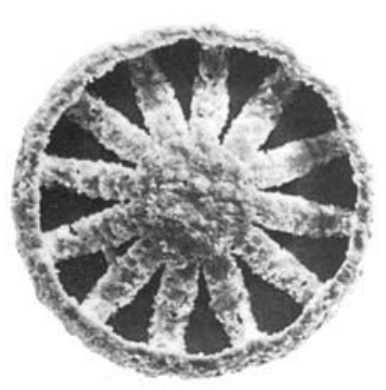

8
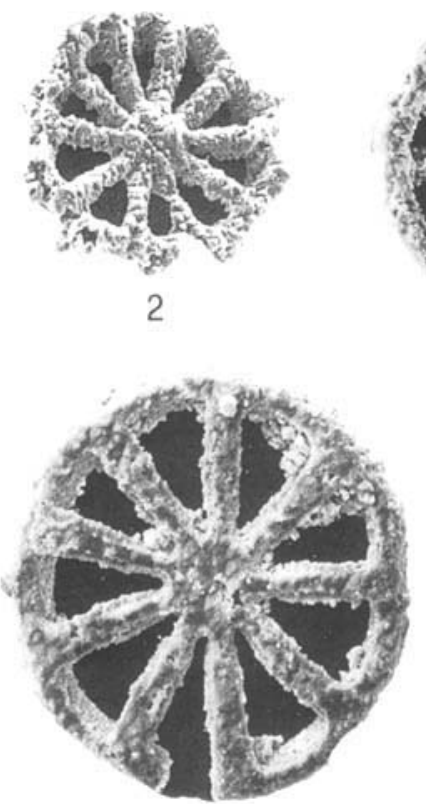

6
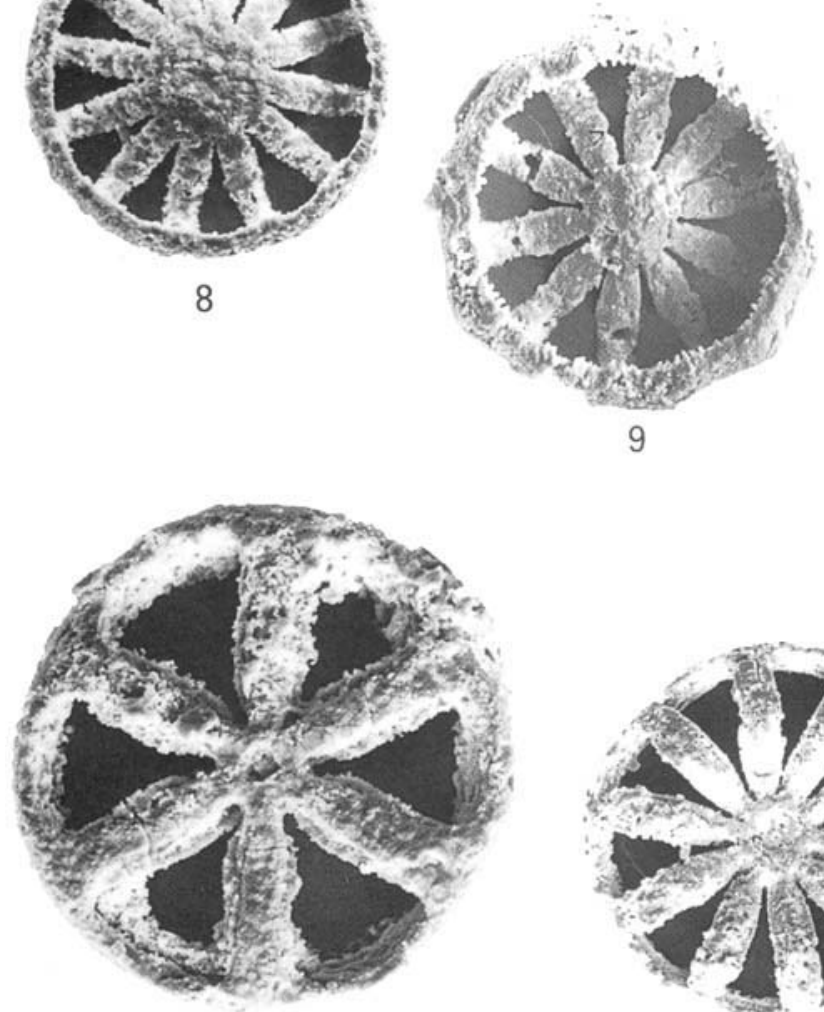

11
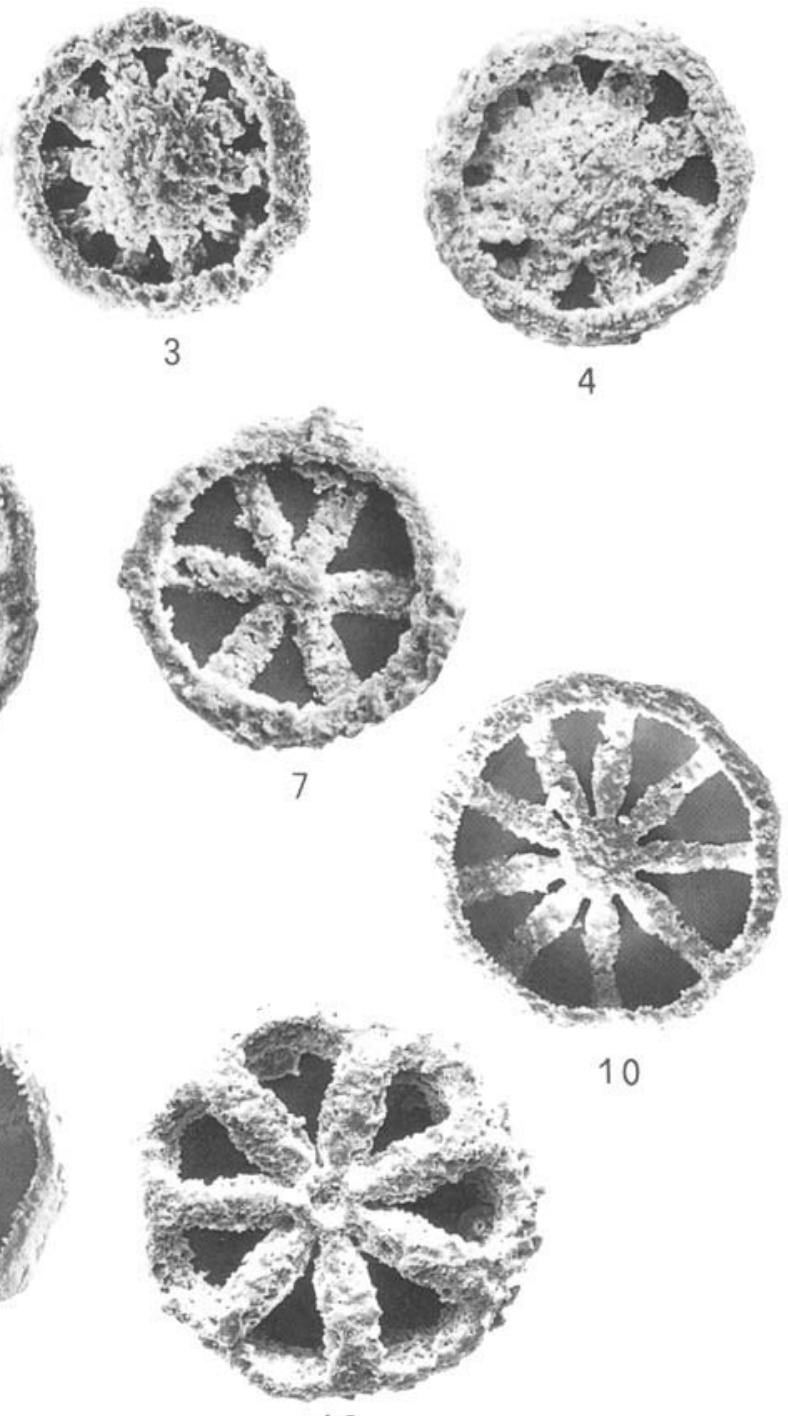

10

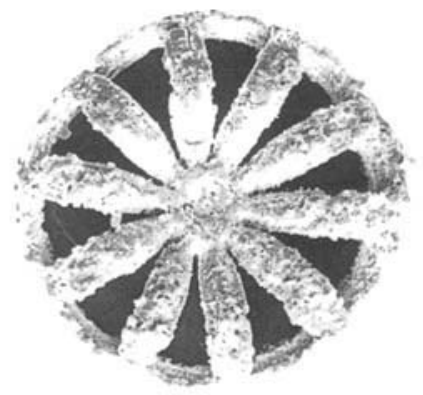

12

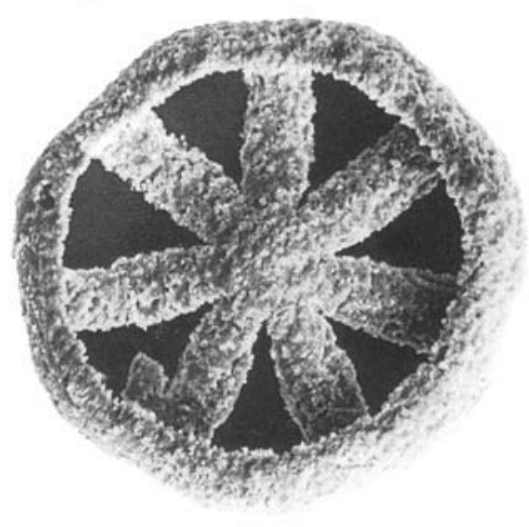

14

Plate 3 
1968 b Theelia planorbicula n. sp. Mostler: 28, pl. 5, fig. 3 1968 Theelia alta n. sp. Speckmann: 208, pl. 3, fig. 1.

Occurrence. Illyrian (late Anisian) of Jordan, from the fossiliferous marly limestone 'Terebratel beds' with Beneckeia spp., Anisian-Norian of Europe, Middle Triassic of India (Himalaya).

Theelia tubercula Kristan-Tollmann, 196.3 (Pl. 2, figs 11-12; Pl. 3, figs 1-2

1963 Theelia tubercula Kristan-Tollmann: 396-370, pl. 8, figs $1-6$.

Material. 50 specimens.

Occurrence. Longobardian and Cordevolian of southern Tethys and its marginal seas.

Remarks. Theelia pralongiae Kristan-Tollmann, 1963 also possesses tubercles arranged like that of $T$. tubercula, but only on the upper surface of the rim. Theelia zankli Kozur \& Simon, 1972 possesses at the outer margin of its rim vertical sharp-ending edges opposite the interspoke spaces. In both the upper and lower vicw, these edges have the appearance of short spines. Occasionally the edges are divided in the middle into two short spines that are located facing one another at the upper and lower part of the outer margin of the rim. These forms have some similarity with $T$. tubercula but without rounded or truncated tubercles and the rim is unsculptured opposite the spokes.

Theelia cf. T. wariabilis slovakensis Kozur \& Mock, 1972 (Pl. 3, fig. 7)

1966 Theolia variabilis n. sp. Zankl: 83, pl. 6, fig. 5a-c, 6-8: 8; pl. 7, figs. 1-5.

1972 Theelia variabilis slowakensis n. subsp. Kozur \& Mock: 23-24, pl. XIl, figs. 7-13, pl. XIII, figs $1-7$.

Occurrence. Uppermost Longobardian of Jordan.

Remarks. The only specimen present is closely related to $T$. variabilis slovakensis, but it is smaller and the spokes are of the same width throughout.

Theelia sp. aff. T. zankli Kozur \& Simon, 1972 (Pl. 2, figs 6-7)

Material. 7 specimens.

Occurrence. Fassanian (carly Ladinian) lowerpart of Salit Formation, logether with Pseudofurnishius priscus (Conodonta) and Schizotheelia jordanica from Wadi Naur ( $P$. priscus zone).

Remarks. The specimens can be compared with $T$. zankli Kozur \& Simon, 1972, (p. 149, pl. 1, fig. 10, pl. 2, figs. 14, 20. 21) from Cordevolian (early Carnian) of southern Spain, but the latter species is larger.
Theelia zapfei Kozur \& Mostler, 1970

(Pl. 1, fig. 12)

1968 Theelia sp. Speckmann: 212-213, pl. 3, fig. 6.

1970 Theelia zapfei n. sp. Kozur \& Mostler: 382, pl. 4, figs 21, 23, 25.

Material. 3 specimens.

Occurrence. Pelsonian of Jordan, Pelsonian of germanic basin and Tethyan Triassic.

Remarks. Theelia zapfei is very closely related to. $T$. subcirculata Mostler, $1968 \mathrm{~b}$ but the latter is larger and has a subcircular outline. Theelia germanica Kozur, 1969 is also very similar, but differs by its larger number of spokes.

Theelia cf. T. zawidzkae Kozur \& Mock, 1972 (Pl. 2, fig. 5)

Occurrence. Illyrian (late Anisian) of Jordan.

Remarks. The only specimen present is very much like $T$. zawidzkae Kozur \& Mock, 1972 from the lower Norian of Slovakia, differing by its smaller size and by having spokes of the same width throughout. Theelia norica Mostler, 1969 from Norian of Steinbergkogel, Austria, which was also recorded by Kozur \& Mock (1972) from the lower Norian of Slovakia is also similar, but differs in having three spokes tapering strongly near the hub and smaller hub.

Family Schizotheelidae Kozur \& Sadeddin, 1992

Genus Schizotheelia Kristan-Tollmann, 1972

Schizotheelia jordanica Kozur \& Sadeddin, 1992

(PI. 2, figs 9-10)

1992 Schizotheelia jordanica n. sp. Kozur \& Sadeddin: 10-14, figs 4, 5a-c, 6a-f, 7b-d.

Material. Several hundred specimens.

Occurrence. Fassanian (early Ladinian) of Jordan, together with Pseudofurnishius priscus Sadeddin, Pseudofurnishius siyalaensis Sadeddin \& Kozur, from Wadi Naur and Wadi Siyala ( $P$. priscus zone).

Description. Hub round, small, lies slightly elevated above the plane of the sclerite on both sides or at the same level, with flat or slightly concave centre. From the hub emanate 7-11, predominantly 9-10) narrow spokes of the same width throughout. Interspoke spaces drop-like, pointing inwards, always larger than outer pores. Spokes are multi-furcated whereby the adjoining branches produce different-sized pores, which generally become smaller outwards. The pores are irregularly shaped; rounded, oval, or drop-like and may be elongated either parallel or perpendicular to the periphery.

\section{Explanation of Plate 3}

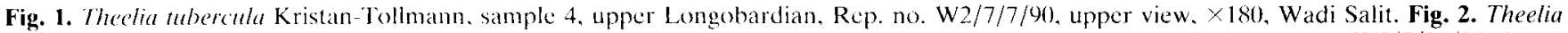

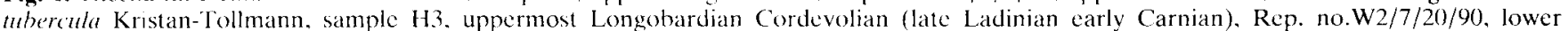

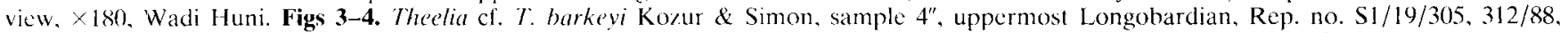

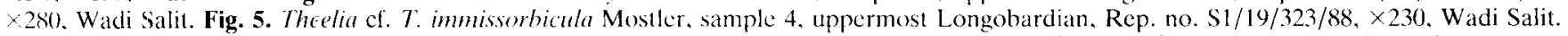

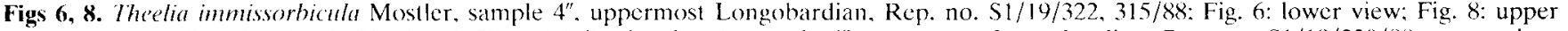

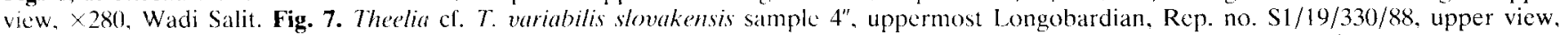

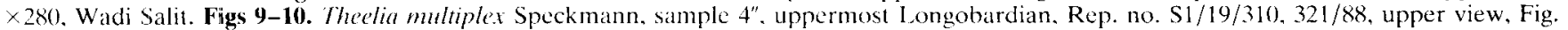

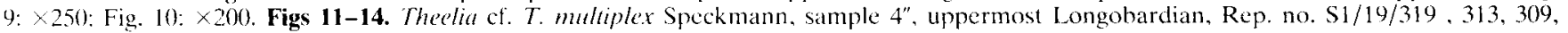
$307 / 88$, Fig. 11; $\times 280$; Fig. 12: $\times 190$; Fig. 13: $\times 195$; Fig. 14: $\times 280$. Wadi Salit. 
Remarks. Schizoacanthotheelia spiniperforata Zawidzka, 1971 from the upper Anisian of west Carpathian and from Cordevolian of Spain, differs from Schizotheelia jordanica by having distally uni- or bi-furcated spokes. Schizotheelia schizomata Kristan-Tollmann, 1973 from Carninan of the southern Alps, has lancet shaped, proximally and distally pointed interspoke spaces and pores. Schizotheelia multiporata Kozur \& Sadeddin has small or unequally sized interspoke spaces.

Schizotheelia multiporata Kozur \& Sadeddin, 1992 (PI. 2, fig. 8)

1992 Schizotheelia multiporata n. sp. Kozur \& Sadeddin: 14-15, fig. 8a -b.

Material. 7 Specimens.

Occurrence. Fassanian (early Landinian) of Jordan, together with Pseudofurnishius priscus Sadeddin and $P$. siyalaensis Sadeddin \& Kozur from Wadi Naur and Wadi Siyala $P$. priscus zone).

Description. Hub relatively large, flat or very slightly arched. Spokes 10-13, short, narrow, The interspoke spaces are long oval-drop shaped, distally rounded. The adjoining pores are large, generally elongate, rarely irregularly shaped. Some of the adjoining pores are larger than the interspoke spaces. These pores are followed distally by different sized but clearly smaller pores. The outer pores are rounded (rarely oval) drop shaped or irregular.

Remarks. Schizotheelia multiporata Kozur \& Sadeddin differs from Schizotheelia schizomata Kristan-Tollmann, 1973 and S. jordanica Kozur \& Sadeddin by its unusual short spokes and small interspoke spaces.

\section{ACKNOWLEDGEMENTS}

The author is indebted to Dr Paul Gilliland, Dr Giles Miller, Professor J. Murray and Dr Jeremy Young for making corrections that improved the manuscript.

\section{Manuscript received January 1994 Manuscript accepted May 1995}

\section{REFERENCES}

Cox. L. R. 1924. Triassic fauna from the Jordan Valley. Annals and Magazine of Natural History, London. 14(9): 52-96.

Etheridge. R. Jr. 1881. On the presence of the scattered skelctal remains of Holothuroidea in the Carboniferous Limestone Series of Scotland. Proceedings of the Royal Philosophical Society, Edinburgh. 6: 183-198.

Frizzell, D. L. \& Exline, H. 1955a. Micropaleontology of holothurian scterites. Micropaleontology, 4: 335-342.

Frizzell, D. L. \& Exline, H. 1955b. Monograph of fossil holothurian scicrites. Bulletin of the Missouri University School of Metallurgy and Mines, Technical Series. 89: 1--204.

Frizzell, D. L.. \& Exline, H. 1966. Holothuroidea-fossil record. In Treatise on Invertebrate Paleontology, Part U, Echinodermata (2): U 646-U 672, Geological Society of America, Kansas University Press.

Gazdzicki. A.. Kozur, H., Mock. R. \& Trammer. J. 1978. Triassic Microfossils from the Korytnica Limestones at Liptovska Osada (Slovakia. CSSR) and their stratigraphic significance. Acta Palaontologica Polonica. 23: 351-373.
Gilliland, P. M. 1992. Holothurians in the Blue lias of southern Britain. Palaeontology, 35: 159-210.

Gilliland, P. M. 1993. The Skeletal Morphology, Systematics and Evolutionary History of Holothurians. Special Papers in Palaeontology No. 47, Palaeontological Association, London, $1-147$.

Gullo, M. \& Kozur, H. 1989. Psetudofurnishius sosioensis n. sp., a new conodont species from the Ladinian of Sosio Valley, Western Sicily(Italy). Geologisch-Paläontologische Mitteilungen Innsbruck, 16: $207-211$

Hodson, F.. Harris, B. \& Lawson, L. 1956. Holothrian spicules from the Oxfordian Clay of Redeliff ncar Weymouth(Dorset). Geological Magazine, 93: 336-344.

Kozur, H. 1968. Conodonten aus dem Muschelkalk des germanischen Binnen- beckens und ihr stratigraphischer Wert. Geologie, 17(8): 930-946.

Kozur, H. 1969. Holothuriensklerite aus der germanischen Trias. Monatsberichte Akademie Wissenschaften, Berlin, 11: 146-154

Kozur, H. 1974. Die Conodontengattung Metapolygnathus Hayashi 1968 und ihr stratigraphischer Wert. Geologisch-Paläontologische Mitteilungen Innsbruck, 4(1): 1-35.

Kozur. H. 1980. Revision der Conodontenzonierung der Mittel und Obcrtrias des tethyalon Faunenreichs. Geologisch Paläontologische Mitteilungen Innsbruck, 10(3/4): 79-172.

Kozur. H. 1989. Significance of Events in Conodont Evolution for the Permian and Triassic Stratigraphy. Courier Forschungsinstitut Senkenberg, 117: 385-408.

Kozur, H., Kampschuur, W., Mulder-Blanken, C. \& Simon, O. J. 1974. Contribution to the ostracode faunas of the Betic Zone (southern Spain). Scripta Geologica, Leiden, 23: 1-56.

Kozur. H., Kampschuur, W., Mulder-Blanken, C. \& Simon, O. J. 1985. On the Triassic of the Betic Cordilleras (southern Spain) with special emphasis on holothurian sclerites. Proceedings Koninklijke Nederlandse Akademie, Series B, 88(1): 83-110.

Kozur. H. \& Mock, R. 1972. Neue Holothurien-Sklerite aus der Trias der Slowakei. Geologisch-Paläontologische Mitteilungen Innsbruck, 2 (12): 1-47.

Kozur, H. \& Mostler, H. 1970. Holothurien-Sklerite aus der Unter und Mitteltrias des germanischen Beckens und alpinen Raumes sowie deren stratigraphische Bedeutung. Festband Geologische Institut, 300-Jahr-Feier Universität Innsbruck, 361-398.

Kozur, H. \& Mostler, H. 1971. Probleme der conodontenforschung in der Trias. Geologisch-Paläontologische Mitteilungen Innsbruck, I(4): $:-19$.

Kozur. H. \& Sadeddin, W. 1990. Holothurian sclerites from the Middle Jurassic of Wadi Huni, northwest Jordan. Micropaleontology, 36(4): 353-366.

Kozur, H. \& Sadeddin, W. 1992. Neue Holothurien-Sklerite aus dem Fassan (Frühes Ladin) von Jordanien. Eclogae Geologicae Helvetiae, 85(3): $853-869$.

Kozur, H. \& Simon, O. J. 1972. Contribution to the Triassic microfauna and Stratigraphy of the Betic Zone (southern Spain). Revista Española Micropaleontologia, Numero extraordinario. XXX Aniversario ADARO: $143-158$

Kristan-Tollmann, E. 1963. Holothurien-Sklerite aus der Trias der Ostalpen. Sitzungberichte der Akademie der Wissenschaften in Wien, Abteilung 1, 172: 351-380.

Kristan-Tollmann. E. 1973. Einige neue mesozoische HolothurienSklerite. Mitteilungen der geologischen Gesellschaft in Wien. 65(1972): 123-136.

Mostler. H. 1968b. Holothurien-Sklerite aus der oberanisischen Hallstätterkalken (Ostaplen, Bosnien, Türkci). Veröffentlichungen der Universität Innsbruck, Alpenkundliche Studien, 7: 1-44

Mostler, H. 1968c. Neue Holothurien-Sklerite aus der norischen Hallstätter-kalken (Nördliche Kalkalpen). Bericht des Naturwissenschaftlichen-Medizinischen Vereins in Innsbruck, 56: 427-441.

Mostler, H. 1969. Entwicklungsreihen triassischer Holothuriensklerite. Veröffentlichungen der Universität Innsbruck, Alpenkundliche Studien, 7: 1-53.

Mostler, H. 1970. Uber einige Holothurien-Sklerite aus der Süd-und 
Nord alpinen Trias. Festband Geologische Institut, 300-Jahr -Feier Universität Innsbruck, 339-360.

Mostler, H. 1973. Holothurien-Sklerite der alpinen Trias und ihre stratigraphische Bedeutung. Mitteilungen der Gesellschaft der Geologie und Bergbaustudenten, Innsbruck, 21(1972): 729744.

Mostler, H. 1979. Ein Beitrag zur mitteltriassischen Mikrofauna von Recoaro und Tretto (Vicentin, Italien). Geologisch Paläontologische Mitteilungen Innsbruck, 9(9): 321-351.

Parnes, A. 1975. Middle Triassic ammonite biostratigraphy in Israel. Geological Survey Israel Bulletin, 66: 1-35.

Sadeddin, W. 1990. Pseudofurnishius priscus n. sp. (Conodonta) and its stratigraphical significance for the Ladinian (Middle Triassic) in Jordan. Neues Jahrbuch für Geologie und Paläontologie, Abhandlungen. 178(3): 369-382.

Sadeddin, W. 1991. Acanthotheelia jordanica n. sp., A new holothurian sclerite species from the Pelsonian (middle Anisian) of Jordan. Rivista Española de Micropaleontologia, 23: 83-88.

Sadeddin, W. (in press). Conodont-Biostratigraphy and paleogeography of the Triassic in Jordan. Palaiontographica abt. A.
Sadeddin, W. \& Kozur, H. 1992. Zum alter und zur geographischen Verbreitung von Theelia tubercula Kristan-Tollmann (Holothurien-Sklerite). Neues Jahrbuch fiir Geologie und Paläontologie, Monatshefte, 5: 292-302.

Schlumberger, C. 1890. Seconde note sur les holothuridées fossiles du calcaire Grossier. Bulletin de la Société Géologique de France. 3e Series, 18: 191-218.

Soodan, K. S. \& Whatley, R. 1987. Fossil Holothuroidea from the Jurassic of Great Britain . Part 1. Journal of Geoscience. 8: $163-174$.

Speckmann. P. 1968. Holothurien-Sklerite aus der Mittel-Trias der Ostalpen. Mitteilungen der Bayerischen Staatssammlung fur Paläontologie und Historische Geologie, 8: 197-218.

Wagner, G. 1934. Deutscher Muschelkalk am Toten Meer. Natur u. Volk, 64(2): 449-454.

Zankl, H. 1966. Holothurien-Sklerite aus dem Dachsteinkalk (Ober Trias) der nördlichen Kalkalpen. Paläontologische Zeitschrift. 40(1/2): $70-88$.

Zawidzka, K. 1971. Triassic holothurian sclerites from Tatra Mountains. Acta Palaeontologica Polonica, 16: 429-450. 